\title{
EVALUASI PENETAPAN BATAS SEMPADAN NGARAI SIANOK TERHADAP BAHAYA GERAKAN TANAH BAGI PERMUKIMAN DI KOTA BUKITTINGGI
}

\author{
Fikri Akbar D, Yurni Suasti ${ }^{2}$, Ahyuni $^{3}$ \\ Program Studi Geografi, \\ Fakultas Ilmu Sosial, Universitas Negeri Padang \\ E-mail :the_glanter@yahoo.com
}

\begin{abstract}
Abstrak
Penelitian ini bertujuan untuk mengetahui bagaimana dampak perubahan batas sempadan Ngarai Sianok terhadap bahaya gerakan tanah pada penataan kawasan permukiman serta penetapan kebijakan batas sempadan Ngarai Sianok terhadap bahaya gerakan tanah bagi pemukiman di Kota Bukittinggi. Khususnya di Kelurahan Birugo, Belakang Balok, Kayu Kubu dan Bukik Cangang Kayu Ramang. Penelitian ini menggunakan metode kuantitatif dengan pendekatan deskriptif. Metode pengumpulan data adalah data sekunder yang di dapatkan dari instansi terkait di Kota Bukittinggi. Teknik analisis data yang digunakan adalah overlay (Tumpang susun). Hasil penelitian menunjukan bahwa (1) Dari analisis overlay menggunakan Citra quickbird Kota Bukittinggi tahun 2010-2015 dalam penataan kawasan permukiman ditemukan adanya pertambahan permukiman yang berada pada kawasan sempadan Ngarai Sianok dan belum ada upaya relokasi yang dilakukan oleh pemerintah hingga saat ini. (2) Perubahan batas sempadan Ngarai Sianok terhadap bahaya gerakan tanah mengakibatkan perumahan yang berada pada potensi gerakan tanah tinggi makin bertambah jumlahnya hal ini akan berdampak jika suatu waktu Kota Bukittinggi mengalami bencana alam yang berpotensi menimbulkan gerakan tanah akan mengakibatkan korban yang sangat banyak.
\end{abstract}

Kata Kunci : Sempadan, Gerakan Tanah

\section{Abstract}

This study purpose is to know the rules of residential arrangement area of the Sianok Canyon, knowing the limitations of changes on the border of Sianok Canyon, towards structuring settlements as well as the determination of the boundary limits of the policy against the dangers caused on sianok Canyon ground motion for settlement in Bukittinggi, especially Birugo Village, Belakang Balok, Kayu Kubu and Bukik Cangang Kayu Ramang. These studies use quantitative methods with descriptive approach. Data collection methods are secondary data that has been obtained from relevant agencies in Bukittinggi. The data analysis technique used is overlay. The results showed that (1) From the results of overlay using the image of Bukittinggi quicbird in 2010-2015 in the arrangement of settlement zones found that settlements occurred in the sianok canyon border zone and there were still relocation efforts carried out by the government at this time. (2) Changes in the border limit of the Sianok Canyon to the danger of land movements that allow economic growth will increase the time that will affect the time of Bukittinggi, a natural disaster on the future could affect many victims.

Key Word: Border, Soil Movement

\footnotetext{
${ }^{1}$ Mahasiswa Program Studi Geografi

${ }^{2}$ Dosen Jurusan Geografi Fakultas Ilmu Sosial Universitas Negeri Padang
} 


\section{PENDAHULUAN}

Salah satu faktor kerusakan bangunan yang terjadi akibat gerakan tanah saat ini bergantung dari kekuatan dan kualitas bangunan, bentuk geologi dan geotektonik serta percepatan tanah maksimum daerah dilokasi gerakan tanah di tuangkan dalam bentuk peta mikrozonasi gerakan tanah (Edwisa \& Novita, 2008).

Sebab itu peta mikrozonasi daerah rawan bencana gerakan tanah bisa dimanfaatkan sebagai untuk mengurangi terjadinya kerusakan di daerah tersebut akibat bahaya gerakan tanah.

Gerakan tanah adalah gerakan yang menuruni lereng oleh tanah ataupun batuan penyusun lereng. Definisi di atas dapat menunjukkan bahwa massa yang bergerak dapat berupa massa tanah, massa batuan ataupun percampuran antara keduanya. Masyarakat pada umumnya menerapkan istilah longsoran untuk seluruh jenis gerakan tanah, baik yang melalui bidang gelincir ataupun tidak. Varnes (1978 dalam Hansen, 1984) secara definitif juga menerapkan istilah longsoran ini untuk seluruh jenis gerakan tanah.

Gerakan tanah adalah salah satu proses geologi akibat interaksi beberapa kondisi antara lain geomorfologi, struktur geologi, hidrogeologi dan juga tata guna lahan. Kondisi tersebut berpengaruh sangat berpengaruh sehingga menyebabkan kondisi lereng yang cenderung bergerak (Karnawati, 2007).

Gerakan tanah bisa dapat di identifikasi berdasarkan tanda-tanda seperti : Timbulnya retak tarik dan kerutan - kerutan di permukaan lereng, patahnya pipa dan tiang listrik, miringnya pepohonan, jalanan yang tiba - tiba amblas, rusaknya perlengkapan jalanan seperti saluran drinase dan pagar pengaman, (Hardiyatmo,2012).

Kerentanan lereng terhadap gerakan tanah didefinisikan sebagai kecenderungan lereng dalam suatu wilayah atau zona untuk mengalami gerakan, tanpa mempertimbangkan resikonya terhadap kerugian jiwa atau ekonomi. Apabila aspek risiko terhadap manusia diperhitungkan, maka lebih tepat diterapkan istilah kerawanan (BAPEKOINDA, 2002).

Kota Bukittinggi adalah Kota yang tumbuh dan berkembang di daerah patahan aktif Sumatera atau yang lebih dikenal dengan daerah Ngarai Sianok. Daerah ini diperkirakan mengalami pergeseran dengan jarak 11 centimeter per tahun. Kota Bukittinggi ini juga diapit oleh dua gunung, yaitu Gunung Singgalang dan Gunung Marapi. Hal ini menyebabkan secara alamiah Kota Bukittinggi berpotensi menghadapi bahaya gempa bumi yang dapat menimbulkan bencana gerakan tanah. Saat ini kita masih dapat melihat banyaknya permukiman yang masih berada di bibir Ngarai Sianok. Untuk mengatasi hal ini pada tahun 2010, 
pemerintah menetapkan Kawasan sempadan Ngarai Sianok dengan jarak 100 meter dari bibir ngarai dengan arah menjauhi ngarai. Sempadan Ngarai Sianok kemudian ditetapkan sebagai ruang terbuka hijau (RTH) dengan fungsi khusus, dan merupakan kawasan strategis untuk kepentingan daya dukung lingkungan hidup yang tertuang di dalam RTRW (Rencana Tata Ruang Wilayah) Kota Bukittinggi tahun 2010-2030 pada peraturan daerah No. 6 Tahun 2011.

Garis sempadan merupakan suatu garis batas pengaman yang ditetapkan sebagai fungsi dalam mendirikan bangunan atau pagar yang ditarik pada jarak tertentu yang sejajar dengan jalan, tepi luar jembatan, sungai, saluran, tanggul, rawa,waduk,mata air,jaringan listrik dan pipa gas, dan itu tergantung jenis garis yang diperuntukan. Di bagian luar dari garis sempadan ini, pemilik tanah tidak diperbolehkan untuk mendirikan bangunan.

Hal ini merupakan bagian dari isi rencana tata ruang. Didalam sistem perencanaan Indonesia terdapat 2 sistem perencanaan yaitu perencanaan pembangunan (development planning) dan perencanaan keruangan (spatial planing). (Ahyuni, 2011).

Garis sempadan di Kota Bukittinggi di atur melalui perencanaan keruangan yang tertuang pada perda Rencana Tata Ruang Wilayah (RTRW). Namun pada revisi perda No. 6 Tahun 2011 sempadan Ngarai Sianok ditetapkan sepanjang minimal 50 (lima puluh) meter dari bibir ngarai dengan luas 102 Ha. Berdasarkan peta mikrozonasi gerakan tanah pemunduran ini mengakibatkan permukiman yang dahulunya harus direlokasi sesuai perda No. 6 Tahun 2011 namun sekarang dibiarkan berada pada zona gerakan tanah tinggi. Oleh karena itu perlu dilakukan penelitian apakah batas sempadan Ngarai Sianok di Kota Bukittinggi apakah sudah memperhatikan bahaya gerakan tanah yang ditampilkan peta mikrozonasi gerakan tanah yang di buat oleh Badan Geologi Kemeterian Energi Dan Sumber Daya Mineral.

\section{METODOLOGI PENELITIAN}

Penelitian ini menggunakan metode deskriptif dengan pendekatan kuantitatif, yang berlokasi di Kota Bukittinggi tepatnya di Kelurahan Birugo,Kelurahan Belakang balok,Kelurahan Kayu kubu dan Kelurahan Bukik cangang kayu ramang pada bulan Mei - Juni tahun 2018. Alat yang digunakan pada penelitian ini adalah Arcgis dengan menggunakan bahan berupa petapeta seperti peta mikrozonasi gerakan tanah dan juga peta permukiman di Kota Bukittinggi. Obyek penelitian dalam tulisan ini meliputi pemukiman yang berada di kawasan Ngarai Sianok. Sedangkan untuk teknik analisis data yang peneliti gunakan dengan cara overlay ( Tumpang susun).

\section{HASIL PENELITIAN}




\section{A. Perbandingan arahan kebijakan penetapan dan penataan permukiman di kawasan Ngarai Sianok.}

\section{Perda No. 6 Tahun 2011 tentang} Rencana Tata Ruang dan Wilayah

Penetapan kawasan sempadan Ngarai Sianok sebagai kawasan RTH dimaksudkan sebagai bentuk perlindungan terhadap keberadaan Ngarai Sianok yang memiliki potensi geologis yang perlu untuk dikonservasi.

a. Penetapan batas sempadan Ngarai Sianok :

Kawasan sempadan Ngarai Sianok diarahkan sepanjang $100 \mathrm{~m}$ dari bibir ngarai baik atas maupun bawah dengan luas 263 Ha. Ketentuan peraturan zonasi untuk lindung setempat meliputi sempadan sungai, RTH Kota, kawasan Ngarai Sianok, dan sempadan Ngarai Sianok sebagaimana dimaksud dalam Pasal 105 huruf g meliputi:

1) Melindungi kawasan dengan tindakan pencegahan, pemanfaatan kawasan pada kawasan sempadan Ngarai Sianok.

2) Dikembangkan dengan kegiatan yang bersifat alami yang mempunyai kemampuan perlindungan kawasan.

3) relokasi dan pencegahan peningkatan kegiatan budidaya yang ada di kawasan sempadan Ngarai Sianok.

b. Penataan permukiman di kawasan sempadan Ngarai sianok:
1) pengembangan kawasan perumahan, yang dilakukan oleh individu dan juga kelompok, harus melalui pengawasan instansi terkait melalui mekanisme Izin Membangun Bangunan (IMB).

2) pengembangan kawasan perumahan yang dilakukan oleh pengembang (developer) dengan skala kecil, harus memperhatikan masalah sistem jaringan jalan, drainase dan juga jaringan air bersih untuk mencegah terjadinya kemungkinan munculnya daerah genangan.

3) pengembangan hunian dengan tipe vertikal (rumah susun) di Kota Bukittinggi, diarahkan untuk dikembangkan pada ruangruang yang telah ditetapkan.

4) intensitas kepadatan tinggi terutama pada kawasankawasan yang berdekatan dan berhubungan langsung dengan kawasan pusat-pusat pelayanan skala kota yang memiliki pelayanan hingga skala regional.

5) diperlukan upaya relokasi permukiman yang terletak pada kawasan-kawasan yang membahayakan keselamatan, seperti pada sempadan ngarai dan sempadan sungai.

Berdasarkan perda No. 6 Tahun 2011 jumlah permukiman yang harus direlokasi adalah sebanyak 351 rumah di Kelurahan 
Kayu Kubu, 317 Kelurahan Bukik cangang kayu ramang, 276 Kelurahan Belakang Balok dan 271 rumah di Kelurahan Birugo.

2. Revisi Peraturan daerah No. 6 Tahun 2011 tentang Rencana Tata Ruang dan Wilayah (RTRW) (Peraturan daerah No.11 Tahun 2017)

Penetapan kawasan sempadan Ngarai Sianok sebagai kawasan RTH dimaksudkan sebagai bentuk perlindungan terhadap keberadaan Ngarai Sianok yang memiliki potensi geologis yang perlu untuk dikonservasi.

a. Penetapan batas sempadan Ngarai Sianok :

Daerah kawasan sempadan Ngarai Sianok diarahkan dengan luas kurang lebih 102 (seratus dua) hektar terletak pada daerah sepanjang minimal 50 (lima puluh) meter dari bibir Ngarai Sianok dengan perencanaan kawasan sebagai berikut:

1) Melindungi kawasan melalui tindakan pencegahan, pemanfaatan permukiman pada kawasan sempadan Ngarai Sianok.

2) pengembangan kegiatan yang mempunyai sifat alami dan mempunyai kemampuan terhadap perlindungan kawasan.

3) relokasi dan pencegahan peningkatan kegiatan budi daya yang ada di kawasan sempadan Ngarai Sianok. b. Penataan permukiman di kawasan sempadan Ngarai sianok:

1) Diperbolehkan untuk tempat hunian baik itu berupa hunian tunggal dan juga hunian bersama, yang tersebae pada daerah kepadatan tinggi, sedang maupun rendah, serta kegiatan pendukung fungsi perumahan.

2) Dilakukan pengendalian kegiatan yang tidak sesuai dengan skala pelayanannya.

3) Dikendalikan pada zona dengan tingkat goncangan tanah relatif tinggi dan sedang.

4) Tidak diperbolehkan kegiatan yang bisa menimbulkan dampak negatif terhadap lingkungan, terutama kegiatan yang berpotensi menimbulkan polusi lingkungan, yang meliputi polusi udara dan air yang dapat mengganggu kegiatan hunian.

Berdasarkan revisi perda No. 6 Tahun 2011 jumlah permukiman yang harus direlokasi adalah sebanyak 141 rumah di Kelurahan Kayu Kubu, 173 Kelurahan Bukik cangang kayu ramang, 170 Kelurahan Belakang Balok dan 83 rumah di Kelurahan Birugo. Namun dari hasil analisis overlay citra quickbird Kota Bukittinggi Tahun 2010-2015 dalam penataan kawasan permukiman ditemukan adanya pertambahan jumlah rumah yang berada pada kawasan sempadan Ngarai sianok dan belum ada upaya relokasi hinggaa saat ini. 
B. Bahaya gerakan tanah terhadap permukiman menurut perda RTRW Kota Bukittinggi sebelum dan sesudah revisi

Dari hasil analisis dengan menggunakan teknik overlay peta mikrozonasi gerakan tanah dengan peta sebaran permukiman Kota Bukittinggi Tahun 2010 dan 2015 didapatkan bahwa pemukiman yang berada pada zona 100 meter berjumlah 299 rumah berada pada zona tinggi, 109 rumah berada pada zona sedang dan 417 rumah berada pada zona rendah, jika dikalkulasikan jumlah keluarga berisi 5 orang dalam satu rumah maka jumlah korban yang ditimbulkan yang berada pada zona tinggi adalah sebanyak 1.495 jiwa. Sedangkan permukiman yang berada pada zona 50 meter berjumlah 717 rumah pada zona tinggi, 211 rumah zona sedang dan 754 rumah pada zona rendah. Jika dikalkulasikan korban akibat bencana di Kota Bukittinggi yang berada pada kawasan sempadan Ngarai Sianok pada tiap-tiap rumah berisi 5 orang maka kemungkinan akan menimbulkan korban sebanyak banyak 3585 jiwa, bahkan lebih mengingat pertambahan penduduk Kota Bukittinggi tiap tahunnya mengalami pertambahan yang signifikan. Sebaiknya untuk zona 50 meter direkomendasikan agar di kaji ulang karna zona tersebut berada pada kawasan zona merah potensi gerakan tanah tinggi, mengingat pertumbuhan penduduk Kota Bukittinggi dalam 5 tahun terakhir megalami pertumbuhan yang pesat dapat dilihat pada tabel 3 berikut:

Tabel 3. Jumlah penduduk Kota Bukittinggi Tahun 2010 - 2016.

\begin{tabular}{llccccccc}
\hline \multirow{2}{*}{ No } & \multirow{2}{*}{ Kelurahan } & Tahun & Tahun & Tahun & Tahun & Tahun & Tahun & Tahun \\
& & 2010 & 2011 & 2012 & 2013 & 2014 & 2015 & 2016 \\
\cline { 2 - 9 } & Jiwa & Jiwa & Jiwa & Jiwa & Jiwa & Jiwa & Jiwa \\
\hline 1 & Birugo & 5735 & 5850 & 5895 & 6102 & 6217 & 6326 & 6694 \\
\hline 2 & Belakang Balok & 2807 & 2815 & 2837 & 2937 & 2992 & 3046 & 3275 \\
\hline 3 & $\begin{array}{l}\text { Bukik Cangang Kayu } \\
\text { ramang }\end{array}$ & 2344 & 2347 & 2368 & 2407 & 2452 & 2493 & 2688 \\
\hline 4 & Kayu kubu & 3512 & 3513 & 3545 & 3606 & 3674 & 3740 & 4029 \\
\hline & Jumlah & $\mathbf{1 4 . 3 9 8}$ & $\mathbf{1 4 . 5 2 5}$ & $\mathbf{1 4 . 6 4 5}$ & $\mathbf{1 5 . 0 5 2}$ & $\mathbf{1 5 . 3 3 5}$ & $\mathbf{1 5 . 6 0 5}$ & $\mathbf{1 6 . 6 8 6}$
\end{tabular}

Sumber: Bukittinggi dalam Angka Tahun 2011-2017.

Tabel 4. Dampak perubahan batas sempadan Ngarai Sianok terhadap bahaya gerakan tanah.

\begin{tabular}{|c|c|c|c|c|c|}
\hline \multirow[t]{2}{*}{ No } & \multirow[t]{2}{*}{ Sempadan } & \multicolumn{3}{|c|}{ Tingkat } & \multirow{2}{*}{$\begin{array}{l}\text { Korban } \\
\text { (jiwa) }\end{array}$} \\
\hline & & Rendah & Sedang & Tinggi & \\
\hline \multirow[t]{3}{*}{1} & Perda RTRW No.6 & 417 Rumah & 109 Rumah & 299 Rumah & 1.495 \\
\hline & Tahun 2011 & & & & \\
\hline & 100 Meter & & & & \\
\hline 2 & $\begin{array}{l}\text { Perda RTRW No.11 } \\
\text { Tahun } 2017\end{array}$ & 754 Rumah & 211 Rumah & 717 Rumah & 3.585 \\
\hline
\end{tabular}


50 Meter

Sumber : Analisis data sekunder.
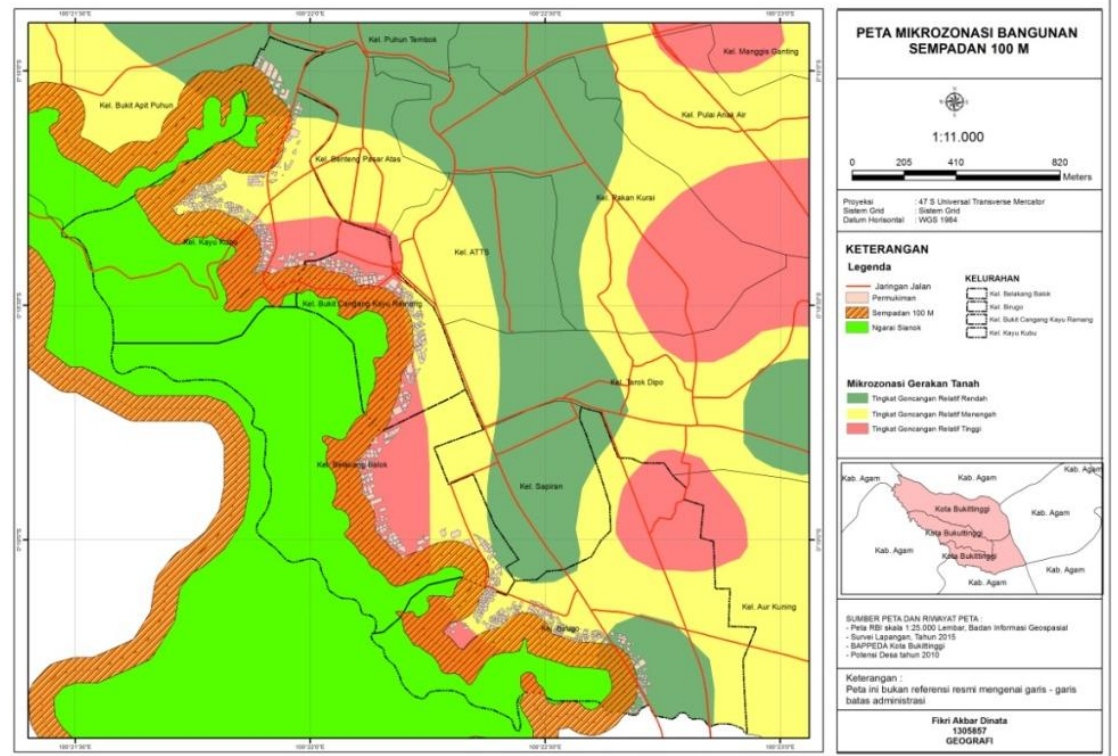

Gambar 3 . Peta Mikrozonasi gerakan tanah dan bangunan sempadan $100 \mathrm{M}$
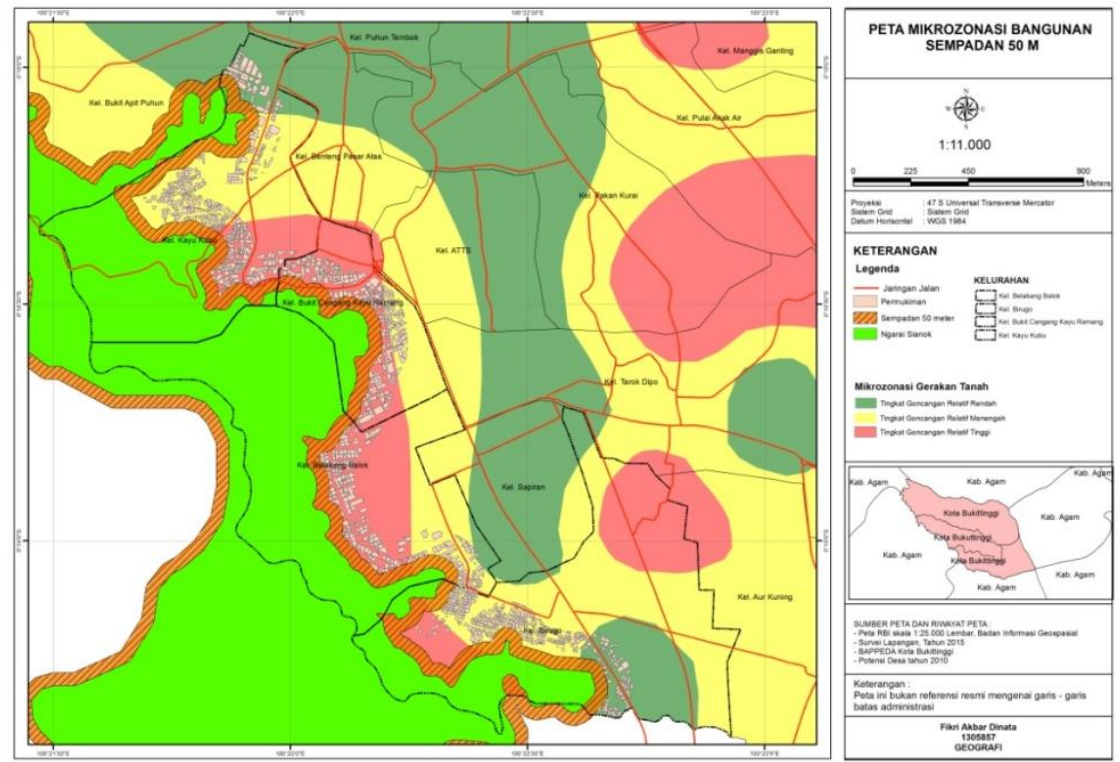

Gambar 4 . Peta Mikrozonasi gerakan tanah dan bangunan $50 \mathrm{M}$

Adapun arahan kebijakan yang di buat oleh pemerintah Kota Bukittinggi terkait bahaya gerakan tanah yang tertuang pada perda
RTRW Kota Bukittinggi No 11 Tahun 2017 dapat dilihat pada tabel berikut:

Tabel 5. Arahan Kebijakan permukiman sempadan Ngarai Sianok Zona Kebijakan 


\begin{tabular}{ll}
\hline Tingkat bahaya rendah & $\begin{array}{l}\text { Diijinkan untuk rumah tempat tinggal, perkantoran, } \\
\text { rumah sakit dan sarana umum lainnya. }\end{array}$ \\
\hline Tingkat bahaya Sedang & $\begin{array}{l}\text { Diijinkan adanya bangunan kecil sekolah, Pusat } \\
\text { pelayanan kesehatan, bangunan pemukiman dan sarana } \\
\text { umum lainnya, dengan persyaratan khusus }\end{array}$ \\
\hline Tingkat bahaya Tinggi & $\begin{array}{l}\text { Diijinkan adanya bangunan untuk umum, yang penting } \\
\text { dan yang tidak dapat dipindahkan, namun dengan } \\
\text { persyaratan khusus. }\end{array}$ \\
\hline $\begin{array}{l}\text { Dilarang adanya perumahan dan bangunan } \\
\text { untuk umum yang baru }\end{array}$ \\
\hline
\end{tabular}

Sumber: Materi teknis revisi RTRW Kota Bukittinggi Tahun 2010 -2030.

\section{KESIMPULAN}

Dari hasil analisis yang peneliti lakukan terhadap permukiman yang berada pada kawasan sekitar sempadan Ngarai Sianok dapat disimpulkan sebagai berikut :

1. Berdasarkan hasil analisis overlay menggunakan Citra quicbird Kota Bukittinggi dengan membandingkan citra quickbird tahun 2010-2015 perkembangan permukiman dari tahun 2010-2015 ditemukannya ada permukiman baru yang berada di kawasan sempadan Ngarai Sianok dan belum ada upaya relokasi yang dilakukan oleh pemerintah hingga saat ini.

2. Perubahan batas sempadan Ngarai Sianok terhadap bahaya gerakan tanah mengakibatkan perumahan yang berada pada potensi gerakan tanah tinggi makin bertambah jumlahnya hal ini akan berdampak jika suatu waktu Kota Bukittinggi mengalami bencana alam yang berpotensi menimbulkan gerakan tanah akan mengakibatkan korban yang sangat banyak.

\section{DAFTAR PUSTAKA}

Ahyuni 2011. Pemanduan Perencanaan Pembangunan dan Perencanaan Keruangan. (PKSBE),Fakultas Ilmu Sosial, Universitas Negeri Padang. http://ejournal.unp.ac.id/index. php/tingkap/article/view/20.

Anto Dajan. 1986. Pengantar Metode Statistik II. Jakarta : LP3ES

Arifin, S.S., Mulyatno, B.S., Marjiyono, \& Setianegara, R. 2013. "Penetuan Zona Rawan Guncangan Bencana Gempa Bumi Berdasarkan Analisis Nilai Amplifikasi Hvsr Mikrotremor dan Analisis Periode Dominan Daerah Liwa dan Sekitarnya" Jurnal Geofisika Eksplorasi 2 (1). 
Arikunto, S. 2010. Prosedur Penelitian Suatu Pendekatan Praktik. Jakarta : Rineka Cipta.

[BPS] Kota Bukittinggi. 2011. Bukittinggi dalam Angka 2011. Bukittinggi : Badan Pusat Statistik.

BAPEKOINDA. 2002. Pedoman Teknis Pemetaan Zona Kerentanan Gerakan Tanah di Propinsi DIY. Laporan Akhir Penelitian. Yogyakarta : Bapekoinda dan Teknik Geologi Universitas Gajah Mada.

Hardiyatmo Christady Hary. 2012.

Tanah Longsor dan Erosi Kejadian dan Penanganannya. Yogyakarta : Gajah Mada University Press.

Karnawati Dwikorita. 2007. "Mekanisme Gerakan Massa Batuan Akibat Gempabumi; Tinjauan dan Analisis Geologi Teknik". Jurnal Dinamika Teknik Sipil, 7 (2). Hlm. 179-190.

Peraturan Daerah Kota Bukittinggi Nomor 6 Tahun 2011 Tentang Rencana Tata Ruang Wilayah Kota Bukittinggi Tahun 2010 - 2030

Peraturan Daerah Kota Bukittinggi Nomor 11 Tahun 2017 Tentang Perubahan Atas Peraturan Daerah Nomor 6 Tahun 2011 Tentang Rencana Tata Ruang Wilayah Kota
Bukittinggi Tahun 2010 2030

Supranto, J. 2000. Statistik Teori dan Aplikasi. Jilid 1 Edisi 6. Erlanggga : Jakarta.

Susanto, A. 2011. Perhitungan Percepatan Tanah Maksimum Berdasarkan Data Gempa Bumi di Daerah Istimewa Yogyakarta. Semarang: Universitas Negeri Semarang.

Varnes, D.J. 1978. "Slope Movement Types and Processes. Special Report 176; Landslides; Analysis and Control, Eds : R.L. Schuster dan R.J. Krizek, Transport Research Board, National Research Council, Washington, D.C" hlm. 11-33. 